\title{
Planned Occurrence
}

National Cancer Institute

\section{Source}

National Cancer Institute. Planned Occurrence. NCI Thesaurus. Code C102557.

An instance of an event or incident that is intended to take place. 